\title{
4. Forests of Gold: From Mining to Logging (and Back Again)
}

JAMON ALEX HALVAKSZ

From here, if you walk towards the Watut, there is timber. ${ }^{1}$ If you go towards Biaru, there is timber. If you go towards Garaina, there is more timber. If you walk down the Markham Valley, towards Madang, you follow the timber. Even in the Highlands, if you look, there is some timber there ... Wau is the true origin of this timber, Wau is its home. (Elauru resident, 2001)

Since the early days of the 1920s gold rush, the upper Bulolo Valley, Morobe Province, Papua New Guinea, has been recognised as a potential source of timber. Early miners used trees to create their camps, fuel their fires, and support the work of panning and mining. As corporate mining took over the principal fields, timber became its backbone. And even as they mined, the expatriate mining community was well aware that the timber had value, that if they could find a route to the coast, the giant klinkii (Araucaria hunsteinii) and hoop pines (Araucaria cunninghamii) might win their weight in gold. The mining community and government officers were so sure of the prospect that they pushed for a road and, barring a road, an aerial tramway to haul timber down to the coast (Lane Poole 1935). Throughout this expansion, Biangai speakers living along the upper end of the Bulolo Valley surrounding the colonial township of Wau have remained on the margins. Many different groups benefited from early gold and timber extraction, but few were Biangai.

1 In Tok Pisin, the term plang was used. This has a number of references, the first being a plank of sawn timber. Here I use the second, referencing timber trees. 
Today, in spite of their political and economic marginality, the Biangai continue to maintain their centrality in the circulation of timber. As noted in the epigraph above, some Biangai claim that Wau is the home of these giant pines, in much the same way that its soils are the source of yams and gold (Halvaksz 2008). In making this claim, my Biangai friend is placing Biangai landscapes at a central node in the global market for timber and other resources. For him, this is a true network - part of a system of gift exchanges between ancestors, Biangai and global markets ${ }^{2}$ — one with ongoing relationships, transactions and, most importantly, obligations. If nothing else, it reaffirms that it is their timber to use.

This chapter examines the efforts of Biangai villagers, Morobe Province, to participate in a local timber market, the relationships that they require and the obligations that they engender. After presenting the broader historical context of Biangai associations with gold mining and commercial forestry, I focus on recent efforts by Elauru villagers to engage in community-based timber production (cf. Salafsky et al. 1997/8). ${ }^{3}$

\section{Making Forests in the Wau-Bulolo Valley}

The only asset that I can see that will replace the wasting product, gold, is timber. The region is purely a forest one, and its climate is decidedly a forest climate ... In short, it is proven forest country. (Lane Poole 1935: 11)

Throughout the boom and bust cycles of gold and the rise and fall of commodity prices for coffee, timber has remained a viable resource. While Lane Poole foresaw a time in which timber would replace 'the wasting product, gold', timber and practices of logging in the area have instead offered some stability through macro and microeconomic transformations. Thus, the value of forests along the upper Bulolo are very much made through the colonial and postcolonial practices of mining, as well as local work of supporting and resisting those efforts. The forests, as such, do not stand apart from the gold.

\footnotetext{
2 Jacka (2001) describes a similar set of obligations deriving from the land itself. Seen as an inalienable possession, the land upon which the mining town of Paiam is situated establishes a set of obligations between the company and Ipili community. Likewise, Biangai conceptualise the land as generative of a seemingly renewable resource, trees for timber. However, in contrast to land, timber is alienable. Still, the exchange of timber retains obligations for reciprocal relationships.

3 Salafsky et al. (1997/8) distinguish community-based timber production from other more inclusive community or social forestry efforts to highlight project emphasis on local timber over non-timber forest products, fuel wood and food production. Community-based timber production is also distinct from industrial timber harvesting as the former emphasises local residence and ownership, and efforts to add value at the point of harvest are less capital intensive and involve local reinvestment.
} 
Analytically, this raises important challenges to existing literature on the construction of state power around forest resources (e.g., Sivaramakrishnan 1995; Li 2007; Winkel 2010). As Sivaramakrishnan (1995) argued, colonial forestry can be as much about knowing the forests as creating systems of knowledge about the peoples that inhabit them. In India, he argues that such systems of meaning continue to inform contemporary practices, creating government technologies for controlling people and resources. Thus,

While forest dwellers were being sorted into types by tribe and caste, the forests themselves were arranged in categories by dominant genera and species. Such description and the laying down of taxonomic structures to represent biotic communities presaged colonial development projects in which human and natural resources were harnessed for imperial purposes. (Sivaramakrishnan 1995: 6)

The colonial project, therefore, organised and controlled people and trees, but also generated discourses of management and conservation that continue into the present. Winkel (2010: 85) notes this point in reviewing the use of Foucauldian concepts in forest policy: 'many colonial forest policy analyses carried out in developing countries also emphasize the continuing prevalence of colonial practices in the postcolonial areas'.

Likewise, Li (2007) has detailed how forest policy shaped colonial and postcolonial relations in Indonesia. However, she extends her discussions to consider the agentive possibilities of community forestry in the assemblage of diverse interests (official forestry departments, conservationists, agroforestry experts, legal advocates, activists, donor agencies and forest villagers). This assemblage is conceptualised as a generative space where diverse 'lines of flight' (Deleuze and Guattari 1987) make different articulations of human agents possible. Forestry practices engage complex networks in and of themselves. But placing them into a wider mineral extraction and agricultural context adds layers to these networks, and reveals discontinuities in state power, as well as possibilities for local empowerment.

During the 1920s and 1930s, when gold was driving the development of Wau and Bulolo (Halvaksz 2006, 2008; see also Sinclair 1998; Waterhouse 2010), forestry mobilised different agencies, even as forest policy was used as a technique for control over both expatriate and indigenous communities. Importantly, government foresters aspired to regulate the exploitation of forests by miners. Aside from revealing discontinuities in the implementation of colonial state power, the history recounted below informs ongoing practices of community forestry today.

Like other areas under colonial control, local populations were accused of deforesting the region through their 'wandering habits and hunting fires' (Taylour and Morley 1933). In a presentation to the Australasian Institute of 
Mining and Metallurgy, Taylour and Morley (as mining warden and assistant mining warden for the Morobe goldfields respectively) noted that the district was 'well supplied with a variety of good timbers' (ibid.: 22), with sawmills 'scattered throughout the main centres of the goldfields' (ibid.: 23). They described miners as making use of the readily available timber resources for housing and mining.

In reading early accounts of the goldfields, the availability of timber is often mentioned either directly as a resource for the industry (as above), or indirectly through descriptions of life on the goldfields. For example, in her account of life in the early days of the goldfields, Doris Booth describes the use of timber by prospectors:

The boys cut down a tree, from which they took a length of about six feet. Then, with an Adze, they chipped out the middle of it, leaving the bottom and sides, and making something like a native canoe. This was about one foot wide and six feet long. When this was completed, they made riffles out of lawyer cane - an oblong frame of network of sticks, like a sieve. This was placed on the bottom of the box, the layers of cane being as close as possible. Then a flume like a wooden pipe was made for the water, which was diverted from the creek into the box. (Booth 1929: 87)

Early on, part of the capital for the emerging mineral industry was created from the forests. Accounts of the goldfields like Booth's express little concern about local timber rights, although government regulations did exist. Thus, timber, like land and water, was intimately linked to the production of gold.

The potential for a productive timber industry was recognised early on. However, it was forestalled, at least in part, because of local demand by the mining industry, but also because of transport concerns. The logistics and costs of building a road to what was then the main north coast port of Salamaua were especially daunting. A slow colonial bureaucracy, perhaps more familiar with mineral claims than timber concessions, also delayed the development. As Charles Booth lamented in a 1939 letter to Pacific Islands Monthly, he had tried for 13 years to gain a licence for 25,000 acres, noting 'When I arrived in the Wau area, in 1924, the first thing that struck me was the wealth of timber' (Booth 1939: 36). The government, following the advice of the inspector-general of forests, sought to license an 'established firm' as the forested area was deemed too small for individuals like Booth (Pacific Islands Monthly 1939: 27; see also Lane Poole 1935). While Booth had proposed water transport, the government 
at the time looked to the completion of a Wau-Salamaua road as a more realistic option. Ultimately, because of these problems, timber production continued to serve local needs in the years leading up to World War II. ${ }^{4}$

In extracting timber for the mining concerns, local practices and rights over such resources were quickly sidestepped. This was done through waste and vacant declarations, as well as devaluing the abilities and understandings of indigenous peoples. Taylour and Morley, in addition to describing the Melanesian population as 'poor specimens, constitutionally weak, backward, and without any form of religion' (1933: 40), also explained that they know 'nothing of rotation of crops', burning and cultivating until they have 'exhausted [the land's] capacity to further produce foodstuff' (ibid.: 23). The 'native' farmer is thus wasteful, but 'under the civilizing influence of the Administration, the Missions, and industrial organisations, the native is improving physically, mentally, and morally' (ibid.: 40-1). Thus, not only were miners justified in their sound use of timber and minerals, doing so would serve the local population as well. Benefiting from the model behaviour of the growing expatriate mining community, they reasoned that indigenous populations would learn to better manage their own resources by following European practices. This discourse of improvement becomes important when considering contemporary conceptualisations of community forestry below. But it also differs from the professional forestry discourses emerging simultaneously with early miners.

In contrast to the emphasis placed on industry use-values by miners and government officials in the mining office, government forestry officials emphasised the potential for an industry and the wastefulness of the mining community. In his 1935 survey of timber in the Morobe goldfields, Lane Poole was concerned with the value of trees and highly critical of the fact that the timber was not being used appropriately by mining companies. Cedar, for example, was used as an 'all purpose' resource when 'durability was necessary' (Lane Poole 1935: 5). After detailing the construction of a water race made completely of pine and cedar, Lane Poole complained, 'I quote this race in detail to show how far the prostitution of timber can go' (ibid., emphasis added). In Lane Poole's vision, different kinds timber have known purposes and the cedar deployed haphazardly in the goldfields would, in his view, be better put to use in the production of 'fine cabinetry' (ibid.). As the inspector-general of forests charged with making recommendations on the use of the resources found in the colony, Lane Poole enforced a set of values that sought to match grain and strength with products, fulfilling, in this case, the wood's finely tuned historical disposition for cedar cabinetry. Making races for mining from such a fine timber

4 At the time, Lae was not deemed a viable port, especially as Salamaua had been established as the coastal station supporting the development of the goldfields. 
was simply offensive. Therefore, he argued that the mining community needed to better use the resources available to them. Miners, in his view, were not the 'civilizing influence' that they imagined themselves to be. They too were wasteful, knowing nothing of timber's value.

In contrast to claims by mining officials, it was not simply a matter of taking it out of local control and imposing colonial management. In another area of the goldfields, Lane Poole spoke favourably of Wahgi Valley forestry practices and the emphasis placed here is revealing:

The destruction of the forests has resulted in a shortage of timber for hutbuilding and fuel; and this has led the natives to adopt a forest policy. Reports from the District and Assistant District Officers - Messrs. Melrose and Penglase - show that the natives in this region and in the Whagi [sic] Valley are making plantations use the Casuarina for the purpose. Timber is counted so valuable that the Government officers are obliged to pay for the tent poles and fuel required for their camps. These primitive people have, through the spur of want, developed a forest policy which shows them to be more fore-sighted then the average of their white brothers in Australia. (Lane Poole 1935: 4, emphasis added)

While Papua New Guineans certainly did not differentiate woods suitable for fine cabinetry, they did manage scarce resources and develop sustainable forestry practices. In contrast, the miners' wasteful 'prostitution of timber' was akin to the destruction of forests by swidden agriculture (which Lane Poole also derided). In both cases, the true values were not maximised.

As Wood (2005) notes, Lane Poole offers a more complex image of the colonial than the caricatures of state discipline described by Sivaramakrishnan. But more importantly for this chapter, it shows discrepancies in colonial authority and a diversity of ways in which forests were deemed useful by the colonial government. It also opens up an intellectual space in which local management is not only viable, but perhaps better than the expatriate mining community's use of the same.

In highlighting what must have seemed an irony from the perspective of colonial policy, Lane Poole also makes a series of recommendations for the development of an industry in the Wau-Bulolo area, which eventually comes to pass as practice. Aside from demanding that a route to the coast be identified, the establishment of regional offices and the training of technical experts, he strongly emphasised the need to develop a market internal to Papua New Guinea such that the colony would be self-sufficient in the production and maintenance of its own timber resources. Community forestry efforts in the village of Elauru reflect this call. 


\section{Logging Biangai Landscapes}

For Biangai, trees are an important part of the social and physical landscape in which they work and live. The forests are home to animals, plants and spirits that are important for sustenance, shelter and cosmology. Hunting paths cut through the forests signify family connections, and stands of economically important fruit and nut trees (especially Pandanus julianettii and Pandanus conoideus) hold named relationships with specific individuals. In mourning songs (or yongo ingi), the soul of the dead is imagined as travelling through forested paths, where specific rivers and trees are evoked to tie the deceased to a lived landscape (Halvaksz 2003). It was perhaps in the construction of a men's house where the relationships between trees, families and people were most clearly displayed. Each family was responsible for providing a single post; one for each corner, the centre walls, a central post and ridge beam. Through its construction, the placement of trees in the men's house marked social relations rooted in land, connecting named kinship groups (solonarik) to each other and to the land from which the building materials were drawn. I argue below that trees made into timber have the potential to be both links in social networks as well as marketable products. But this also requires that we view the market more broadly as an essential network.

Community forestry was largely introduced into Papua New Guinea by missions and coastal plantations (Martin 1997). However, as detailed above, the WauBulolo Valley has a unique relationship to such practices as they emerged in conjunction with gold mining. In the 1920s, small-scale timber operations initially supplemented the profits of both individual miners and the operations of the larger groups that eventually came to dominate the valley (Healy 1967; Sinclair 1998). The industry took off as the two larger operations, Bulolo Gold Dredging and New Guinea Goldfields, developed profitable timber subsidiaries that were key industries in the post-World War II mining economy. ${ }^{5}$

At first, companies acquired timber rights on government lands around the townships of Wau and Bulolo. Once they had expended the timber in those areas, New Guinea Goldfields began to negotiate with the neighbouring villages, including Biangai. Attempts to access stands closer to Wau were made in 1967-68, with New Guinea Goldfields seeking permission from the Department of Forests for timber rights on two areas of 'native owned land' (Lae Archive 1963/68: 26). The communities, it was emphasised in the supporting correspondence from District Commissioner H.P. Seale, were 'very keen to

5 Bulolo Gold Dredging eventually established a plywood factory in 1952. Surrounded by klinkii and hoop pines, Bulolo would become the centre of forestry and forestry research with the establishment of the Bulolo Forestry College. To this day, Bulolo continues to be a centre of forestry activities. 
go ahead' (ibid.: 184). However, after an investigation by a forest officer, the department director expressed concern that 'the timber is very scattered, that the locals are more interested in an access road rather than a large cash payment, and that considerable work will be required of one of [the government's] officers to determine ownership' (ibid.: 63). Similar motives can be seen in subsequent logging deals discussed below and they reflect generally different goals and desires for partaking in timber schemes.

It was under the newly passed Forestry Act 1973 that Elauru, Winima and Werewere, the three villages furthest from the town of Wau, became participants in the timber industry (Mitio 1981, 1984). The Forestry Act (Amalgamated) 1973 provided two processes for gaining access to timber. The first allowed for the declaration of a Native Timber Authority, a licence that allowed direct dealings between companies and communities over small areas of land. Under such schemes, logging was allowed only in so far as it fulfilled the construction needs of the company. In the second, the state acted as a broker in negotiating a Timber Rights Purchase agreement on behalf of communities. Elauru first contracted with New Guinea Goldfields under the smaller Native Timber Authority. But eventually a Timber Rights Purchase agreement was also negotiated on their land. Their experiences with the two arrangements contrast greatly.

In their version of this history, Biangai initiated the contact, as they were eager for the sorts of benefits accrued by the Biangai communities closer to the town of Wau. An elder described the events as follows:

The story goes like this. A road just doesn't appear out of nothing, but it comes from the efforts of this village, Elauru. This land was here and the company sent word that it would like the trees in our forests. A good number of us, all papagraun [landowners], went to the NGG [New Guinea Goldfields] office and said to them, 'Why are you looking for trees? We have trees.' They asked, 'Where?' We told them in Elauru, and they wanted to know what kinds. We said, bush trees and a kind of pine tree, and the next day they came to look. (interview with Elauru elder, 2002)

As Elauru villagers tell the story, they were eager to have their land logged as it meant the extension of the road to their village, facilitating access and transport between their homes and the town of Wau. It was development as they understood it. But a road is more than just a path through the valley. Like hunting paths followed by men, or the winding routes that they take to their gardens, roads enfold histories, social relations and stories. Roads shared by family bind that family together, and one might expect that a logging road implies more than a practical relationship to the space. Such relations, and the desire to establish and maintain them, are not captured in the director of forests' concern that Biangai are more interested in roads than cash payments. In fact, 
roads have more meaning. In his narrative, the Elauru elder is staking a claim on the relationships that the road makes possible. In this account of the coming of the road, these sentiments are apparent:

R: They carried bows and arrows, two women in front, pulling their bows tight. Other women came behind singing, behind the two in front. They came all the way up to this point.

Jamon: The road crews were there too?

G: They were at the ceremonial gate below, passing through with us.

$\mathrm{K}$ : All of the men and women were performing singsings, pulling them up the hill, and a bulldozer pulled a tree behind the women.

G: Now they came up, passing all of us up to the edge of the trees.

Jamon: This was the first tree they had removed from the ground?

All: Yes

[they restate some of the details again]

Jamon: Now, the women were pulling their bows?

K: Yeah.

Jamon: Why?

$\mathrm{K}$ : Oh man ... [starts to laugh] ... because ...

R: They didn't want to kill them!

$\mathrm{K}$ : They wanted to kill the whites, or maybe the driver. [laughing, others join in]

K: [still laughing] To show them that it is enough that one of them would get this arrow here [points to chest], but ... it's ok

G: We said, 'Now, God's word has come, the church is here, and it is ok ... take our trees and go'.

K: So, they took half from one area. Finished with that, they took half from places where we hardly ever go. That's ok, we said, you can take them and go. And us, as angry as we should be, enough that one of you took this arrow too, but ... [laughs]

The trees were not simply disposable, and their removal was a significant event. But the road was marked as well through the performance of leading the bulldozer along the newly created path; a parade of sorts celebrating the connection between company, communities and the town of Wau. ${ }^{6}$ That they might kill the company employees was funny, but the parade was marked by sadness (women remember crying on such occasions). The account reflects the sort of playful, yet real, tension that is demonstrated in Biangai debates about land and resources; one that is highlighted in their relationship with past and present development partners. Songs were also composed for the occasion.

6 The practice of pulling guests into a meeting is common. On numerous occasions, I witnessed, or was myself the subject of, such performances. 
These were songs of sorrow, or yongo ingi (literally, women's songs), for the loss which the women sang as they tightened the strings of their arrows. Yongo ingi mark the passing of a loved one, noting their emplacement on the landscape, where they came from, where they will journey too; revealing relationships among the living and the dead, human and non-human (Halvaksz 2003). The songs composed for this occasion marked a similar passing. And as with the death of a family member who died too soon, where sorcery and mischief were suspected, they prepared their bows and arrows for the occasion. Removing the trees evoked connections with ancestors, ones that were forgone for the sake of a new relationship with the company, and through the company-created road, to the town of Wau.

But the final detail, the piecemeal extraction of timber from different locations, is important to the valuation of the trees as well and the extension of social relationships beyond the ancestral ones. Timber removed from different locations distributed compensation and established ties between specific Elauru landowners and New Guinea Goldfields. When evaluating the different regimes that have sought Biangai resources over the years (mining, logging, conservation, cash cropping), Biangai always spoke highly of logging. Many favoured it because of the distribution of benefits, as well as the enhanced communal social relations established with the representatives of the company. Contemporary gold mining concentrates on a single location, focusing the network on a smaller group, while logging can activate a much more expansive group of kin as timber is dispersed across the landscape. Biangai preferred the latter.

Under the Native Timber Authority, villagers were actively involved in 'witnessing' the selection and cutting. Individual landowners participated in identifying areas and measuring logs, and were paid according to an agreed price per super foot (see also Mitio 1981). Disputes were limited mostly to families, which is not to say that they were not substantial. Compensation money from logging was fought over, but more often than not redistributed somewhat fairly and with a great deal of investment in projects that spoke more of a commitment to relationships than to self-interests. For example, Elauru villagers spent a large part of their compensation on the construction of a permanent church building, using store-bought materials and employing a carpenter from the coast. Additionally, families receiving compensation payments used some of the money to cover their ancestors' graves with multi-tiered cement monuments. When I asked why this was done, it was said that these ancestors also hold title to the forests, and 'you have to treat them well'.

In contrast, Timber Rights Purchase agreements resulted in much broader disputes, both among families and between villages. Mitio (1981, 1984) analyses the disputes that eventuated between Elauru and Werewere as the forestcovered hills between the two villages were declared a Timber Rights Purchase 
area by the government. His discussion emphasises the lack of close contact between resource owners and the daily practices of the logging companies. Mitio concluded that these disputes resulted from colonial assumptions about the organisation of all Papua New Guinea communities into unilineal clans, when in fact the Biangai are cognatic, granting both men and women rights in resources. Individuals can hold multiple titles in different named resource groups called solonarik, making the assignment of individuals to clans a futile process. Yet, this was done at the beginning of the Timber Rights Purchase agreement, and continues to inform (or confuse) debates around mineral compensation today. As royalty payments were made to 'officially' declared clan leaders without clear identification of which specific timber resources were in question, those with secondary, or even primary, rights in a specific tree might never be compensated and, more importantly, they might not be acknowledged as part of the benefiting group. ${ }^{7}$

The contrast between these two approaches to timber extraction highlights three important factors for contemporary community-based timber production. First, in addition to the short-term financial gains, through participation and employment in the Native Timber Authority, villagers gained experience in forestry that remains useful. As discussed below, it was through employment that individuals learned skills that have ensured the longevity of communitybased timber production. Second, smaller projects that provided direct returns to specific right holders were less likely to lead to disputes and more likely to result in some sort of locally meaningful investment. Third, and perhaps most significantly, the Native Timber Authority allowed for a greater sense of participation and control over the process, if not the actual practices. Subsequently, community members evaluated this experience more positively.

The employment of Biangai men during the Native Timber Authority agreement increased their sense of control as they ensured a greater degree of transparency through participation in the logging and processing of their resources. One of those employees, $\mathrm{K}-$, benefited greatly from working with New Guinea Goldfields. At first hired for manual labour, he was eventually trained in the operation of much of the equipment, tripling his income in the process. At one point, he was given his own crew and a company certificate in chainsaw operations. While he described working with the chainsaw as 'good work', he complained that if he went to work for a company, 'it would be like living in a prison'. Unable to take

7 The disputes between villages follows a similar logic, and continued during my research in 2002 as a group of Werewere villagers tried to establish a cattle project on the area that was cleared by logging. 
breaks when he wanted, or work on different parts of the job, he would feel trapped, lacking control over his own life. Perhaps this sentiment is a factor in shaping how community forestry is practised today. ${ }^{8}$

\section{The Kuper Range Wildlife Management Area}

The Kuper Range Wildlife Management Area began in 1989 after discussions between Wau Ecology Institute (a local non-governmental organisation (NGO)) and Elauru village. Identified as part of a priority area for biodiversity conservation (Beehler 1993; Sekhran and Miller 1995), and coupled with the Wau Ecology Institute's desire to move its overrun Kaindi research station, the Kuper Range was established in 1992. Initially 500 hectares of land was offered by a group from Elauru. ${ }^{9}$ The use of this facility by tourists, researchers, students of the Bulolo Forestry College and a National Geographic film crew increased village interest in the project and more families contributed land. Throughout, the conservation area was couched in terms of it meeting the expectations of development (see West 2006 for similar development discourse). The Wau Ecology Institute encouraged such thinking, funding numerous 'sustainable' development projects. ${ }^{10}$ Along with beekeeping, a pig farm, handicrafts, bottle recycling, a small trade store and ecotourism, a small-scale community forestry project was included for $\mathrm{K}-$ and his family. Wau Ecology Institute used K3,000 to purchase a chainsaw, tools and a limited supply of fuel and oil. In addition, training was promised in ecological methods and equipment maintenance. While the training never eventuated, $\mathrm{K}$ - and others possessed enough experience and ingenuity to continue a community-based forestry project. Of the many projects funded, it is the only one that was still in operation at some level in 2005.

Early on, using chainsaw milling, $\mathrm{K}$ - was able to bid on and gain a number of contracts in and around Wau, in addition to casual labour for Wau Ecology Institute. The field station manager, who was charged with maintaining the paths around the proposed conservation area, was given a second chainsaw. But as discussed below, it too became significant in the local village-based

8 Seeking a change in his life, $\mathrm{K}$ - applied to become an evangelist, and was accepted by the Lutheran Church's school in Finschaffen for training. For some 10 years timber did not play a major role in the lives of Elauru villagers. Shortly after K- left for training, New Guinea Goldfields closed its sawmill in 1976, having failed to comply with stipulations of the Forestry Act (Sinclair 1998: 442). The company did not have a formal development plan for managing the forest areas under its control. Its contract in Elauru was left unfinished. When the idea emerged to start an eco-timber project in association with a small-scale Wildlife Management Area, $\mathrm{K}$ - was ready to participate.

9 Gold prospecting and squatters at Kaindi made the area less useful for biological research into Papua New Guinea's unique flora and fauna.

10 The Wau Ecology Institute received a grant from the New Zealand High Commission to fund a landowner incentive project. The institute stated two objectives in this grant: (1) to assist Elauru villagers in officially registering the Wildlife Management Area and (2) to establish an incentive program that would 'compel people not to sell their forests for commercial logging' (Wau Ecology Institute n.d.: 10). 
economy. With the exception of the field station and ecotourism, none of the projects proved to be year-round successes. Many are long forgotten, and even ecotourism, once subject to the temperamental relationship between the NGO and the community, ended in 2003. Their relationship deteriorated as villagers increasingly questioned Wau Ecology Institute's expenditures, and NGO staff became annoyed with weekly requests from Elauru villagers for compensation, development and/or support.

Throughout, $\mathrm{K}$ - remains a visionary, constantly planning ways to improve his project. He imagines opportunities, and programs that will empower not only himself, but other villagers as well. He spoke to me often about how his project would expand with consistent access to transport and better equipment. But most notable was his vision of a certification program that would allow him to train and certify other Biangai in the use of the chainsaw. He would teach others the skills necessary for participation in the community-based timber production project and employment opportunities in the local labour market. ${ }^{11}$ In the meantime, his success has been limited to bidding on local contracts and acquiring occasional work removing trees that threaten to fall on village homes, or using crude chainsaw milling methods to cut lumber for local use.

\section{Biangai Forestry and the Community}

The lack of economic success and full-time commitment to the community forestry project ensures that it never meets the expectations of international aid agencies and NGOs. Many would not even deem this a community forestry effort. Elauru's community effort neither grows, nor increases profits from year to year. Instead, the project continues to make meagre economic returns, without ever really completely falling apart. In part, this results from the retention of skills and equipment necessary to maintain the project. Furthermore, while much of the area has been logged, the timber resources are not entirely depleted, as with some areas in Papua New Guinea. But more importantly, the local demand for sawn timber remains, even if only on an intermittent basis. This is demonstrated in the village housing market.

Houses in Biangai villages are always under construction. Bundles of bamboo, posts symmetrically embedded in the ground, and skeletal walls temporarily braced against the wind can always be found in some corner of the community of Elauru as families work at replacing old deteriorating structures. They are not company built, but built with the help of many kin, and this construction

$11 \mathrm{He}$ also imagines his own 'integrated conservation and development project', one that is full of contradictions. On one hand, he wants to recreate the facilities of Wau Ecology Institute on his family's land, cutting the timber needed and constructing offices, a hostel, laboratories and a zoo on his own. However, he would do so using timber from the very forests that serve as the centrepiece of the conservation area. 
process adds meaning to the structure. When I helped hammer or carry a post or supplies, the homeowner would laugh and say that they will always think of me when they stand near the nail that I had just pounded in. Such comments were also applied to houses that were finished, as they reminded the residents of kin who had passed away, or moved to distant towns. My adoptive mother in Elauru often recalled how the walls of their house (made of hand-shaped planks fitted like siding) were originally used in the 1950s by her father. The flooring of sawn timber was from the house of my adoptive father's father, made from New Guinea Goldfields' staff houses built during the initial logging operations. His house was torn down at the end of a period of mourning a year after his death, and the usable components now circulate in the homes of his children as reminders. The timber, cut by New Guinea Goldfields from plots of land connected to the family, becomes part of an extended memory, folding the tall pines of the past landscapes, homes and lives into present buildings and contemporary social relations.

Houses are often recycled in this way. During research in 2000-02, Winima village was in the process of moving as the government had deemed it in danger of being destroyed by landslides. Instead of building entirely new structures, each building was almost entirely recycled into the new location. Houses and house parts travelled along the road, with only the most significantly worn pieces replaced by new bush materials. Such recycling serves as a memory of past labour and past labourers. The destruction of an old home can be quite emotional, especially if it is the home of one who has recently died, or was built with the help of such persons. A post bares both the connection to the land and the 'hand mark' of human labour.

The typical house embodies the work of an entire extended family, and the forests that they command. Construction begins with the cutting of hardwood posts, often designated for such purposes a year or more in advance. Cut marks made across the base of a tree confirm its eventual purpose. After posts are designated, the trees are felled and shaped by hand with axe and machete, and left to dry. A single post could take a half-day to shape. The frame of the house is a similarly intensive production, accumulated over the course of weeks if not months. Only the bamboo and kunai are assembled in the final moments, as neither can sit too long and remain useful. Their assemblage indicates the final stages, with the threading of grasses for the roof, and splitting and weaving bamboo floors and walls. Often, such work might entail an entire community. Forestry practices facilitated this work, and were valued for making homes and wood products that would outlast their predecessors. Y-'s house offers an example of such practices. 
Prominently situated at the entrance to the village, Y-'s house was slow to take shape. For months, 16 iron posts stood alone in his area. These were purchased at a considerable discount through a relative who was the headmaster at the vocational school in Wau where students are trained to make such products. Many watched with excitement and amusement as $\mathrm{Y}$ - and a teacher from the elementary school carefully marked the area, and checked that the posts stood perfectly upright before they poured in the cement. But then, nothing else happened. More than six months passed, and the posts remained unattended.

One morning while most of the community was preparing to spend the day in their gardens, there was much movement around Y-'s forever-emerging home. Towards the end of the coffee season, he had purchased fuel and oil for one of the two village chainsaws and work had long been under way in a small crop of trees on his land. Using this fuel, the operator would be able to cut timber for both $\mathrm{Y}$ - and himself. The delay came from the difficulty that the chainsaw operator was having with fashioning the many sizes and transporting the finished products from the bush to the village. They managed to cut the thicker cross beams for the floor, walls and roofs, but the thinner sizes kept splintering and breaking under the crude method of chainsaw milling. With the materials finally carried to the village, $\mathrm{Y}$-'s floor started to take shape.

Some months passed, and $\mathrm{Y}$ - and his extended family had finally raised enough money through the sale of coffee to purchase the remaining timber from a neighbouring village sawmill in Wandumi and from an expatriate in Wau who purchases stands of timber to operate his portable sawmill. The timber and its transport cost money, but $\mathrm{Y}$ - viewed the expenditure as worthwhile. Other villagers were equally impressed, as only three other homes were made of sawn timber, most of which was taken from logging camp scraps. The walls of his house finally started to take shape.

$\mathrm{Y}$ - told me, 'everyone has already said, you are building a real house ... just like those in town ... not at all like a village house'. But this was far from the complete story. While it looked much like the homes in the town of Wau, he had not constructed his house in the same way as a 'town' house. Instead, using his limited funds, he had mobilised his network of kin and other relations around this effort. Much of the money for timber and supplies, as well as the cups of tea, plates of rice and canned meat to feed those who worked a few hours raising his walls and roof, came from his extended family.

While the expatriate mill did not cut him a deal, his family in Wandumi helped by saving 'flawed' pieces for him to purchase at a discount. A relative employed by the Works Department in Lae, and another who was the headmaster of Wau's vocational school, both supplied him with money and 'excess' supplies from their stores. Many in the community (myself included) hammered and sawed, 
donating labour and tools towards the effort. Most of the newly constructed houses in town were built using prefabricated forms, purchased in Bulolo and assembled by local carpenters, if not by their future residents. Y-could not afford such expenses, but he could utilise his network of kin and the availability of skilled community foresters in his efforts. Many now plan to build similar homes, suggesting an increase in local demand for timber products. With the opening of gold mining at nearby Hidden Valley, it was likely that increased cash flows would facilitate this effort.

\section{Conclusion: Determining Success in Community Forestry}

In his review of community forestry in Papua New Guinea, Martin noted the collaborative potential for such efforts, as the influx of 'small-scale forestry, indigenously owned and managed, offers a theoretical potential for diverse interest groups to realise their objectives in cooperation with each other' (1997: 270). These groups seek to address ecological, economic and political concerns providing sustainable alternatives to large-scale resource extraction (such as described in Filer with Sekhran 1998). Others have concluded that such projects contribute positively to community and environmental sustainability (Salafsky et al. 1997/8). However, the systematic lack of training and reliable transport, overreliance on local markets, internal friction, and project sustainability continues to hinder community-based timber production. Furthermore, Martin is critical of part-time efforts that fail to meet commercial standards as communities are torn between social obligations (such as funerary expenses and feasts, subsistence and cash-crop gardens, and village politics) and full participation in community forestry activities. From the perspective of sustaining a capitalist system of timber production, full-time participation is necessary for project success.

In contrast, Gilmour and Fisher (1997: 28) argued that regardless of economic motivations, community forestry is essentially about access to and control of forest resources' (see also Peluso 1992). This suggests a slightly different point of analysis; one that focuses on local empowerment, where political and social sustainability are privileged over economic profitability. As Bun and Baput (2006) point out, community forestry is a process and is different from industrial logging where quick profits are the goal. Here, I have argued that while Biangai communities struggle to succeed according to a formal economic model, they do succeed in terms of providing villages with alternative practices and opportunities that they might otherwise not enjoy. Such successes raise questions about development models, whether they are labelled sustainable or not. Instead of focusing on profit, export markets and the imposition of a strictly 
capitalist model, I argue that such projects help extend the base of community resources, allowing for innovative and creative engagement within a transitional economy (Gudeman 2001). Moreover, we must attend to the different valuations of trees as timber and trees as embedded in community networks (Leach 2001). As objects that 'circulate', trees and their parts become differently entangled in systems of meaning that simultaneously facilitate both Biangai and corporate values. Values are at play when trees transact relationships among Biangai. And they are at play when Biangai, trees and their products engage in wider networks of exchange. Trees for Biangai are not simply utilitarian items of market value. Even when used in the building of homes, the value of trees is as much about the relationships they evoke as the qualities of the species themselves.

More broadly, Gudeman (2001: 158) has argued that development results not from capital accumulation 'but from innovation in the relationships of society'. Such innovations result not merely from capital investment, technical transfer and education, but even in an age of globalisation innovation emerges from social networks. House construction is not a novel development for communitybased timber projects (Filer with Sekhran 1998: 299). Critiques of such practices emphasise the diversion of labour from more profitable endeavours and towards providing for local needs. However, I argue that as they provide opportunities for local innovation, the development of a specialised rural labour and improved living standards with more permanent structures, such projects are successful at extending the economic base of communities, and thus future opportunities. In many ways, contemporary Biangai practices follow the model of early goldminers, where forest resources are affordably accessed so that effort can be given to other development efforts. During the time under consideration, coffee, conservation and gold offered other 'development-like' benefits. Coupled with forestry, Biangai can be seen as creatively engaging diverse economic opportunities.

New Guinea Goldfields has already extracted the most profitable tracts and a nearby company, PNG Forest Products, continues to fill the broader regional demand for milled timber, but at prices beyond the local village. The timber demands of the Biangai communities around Wau are intermittent, based on seasonal cash flows from coffee sales, and a limited, but growing, interest; particularly as the Biangai are attracted to all things modern. Thus, it remains important that they have local resources to meet their needs (as Lane Poole once suggested). The community forestry projects in Elauru, as well as neighbouring Wandumi, seem to be doing just that.

While not meeting NGO and capitalist expectations for growth, Elauru's community forestry efforts suggest much more about community sustainability, focusing attention on developing an economic base and community independence 
in contrast to a reliance on fluctuating markets and dependence on the external advising of temperamental NGOs. K-'s many plans also show the promise of this effort, one that is not captured in the analysis and critique of similar projects. As NGOs and international donor agencies rush to fund community-based timber production, it is import to acknowledge that there are different measures of success.

\section{References}

Beehler, B. (ed.), 1993. Papua New Guinea Conservation Needs Assessment (Volume 2). Washington (DC): Biodiversity Support Program and Boroko: Papua New Guinea Department of Environment and Conservation.

Booth, C., 1939. 'New Guinea's Timber Wealth: A Pioneer's Experience at the Hands of Bureaucracy.' Pacific Islands Monthly, 16 May.

Booth, D., 1929. Mountains, Gold and Cannibals. London: Morrison and Gibb.

Bun, Y.A. and B. Baput, 2006. 'Community Forestry Benefits Customary Landowners: Case Study on Madang Province Papua New Guinea.' ITTO, Forest Trends, Rights and Resources Initiative (CFE Case Study Report).

Deleuze, G. and F. Guattari, 1987. A Thousand Plateaus: Capitalism and Schizophrenia. Minneapolis: University of Minnesota Press.

Filer, C., with N. Sekhran, 1998. Loggers, Donors and Resource Owners. London: International Institute for Environment and Development in association with the PNG National Research Institute (Policy That Works for Forests and People, Country Study 2).

Gilmour, D.A. and R.J. Fisher, 1997. 'Evolution in Community Forestry: Contesting Forest Resources.' In M. Victor, C. Lang and J. Bornemeier (eds.), Community Forestry at a Crossroads: Reflections and Future Directions in the Development of Community Forestry. Proceedings of an International Seminar held in Bangkok, Thailand, 17-19 July 1997 (RECOFTC Report 16).

Gudeman, S., 2001. The Anthropology of Economy: Community, Market, and Culture. Malden (MA): Blackwell Publishing.

Halvaksz, J.A., 2003. 'Singing about the Land among the Biangai.' Oceania 7(3): 153-69.

Halvaksz, J.A., 2006. 'Cannibalistic Imaginaries: Mining the Natural and Social Body in Papua New Guinea.' The Contemporary Pacific 18(2): 335-59. 
Halvaksz, J.A., 2008. 'Whose Mine Closure?: Appearances, Temporality and Mineral Extraction along the Upper Bulolo River, Papua New Guinea.' Journal of the Royal Anthropological Institute 14(1): 21-37.

Healy, A.M., 1967. Bulolo: A History of the Development of the Bulolo Region, New Guinea. Canberra: The Australian National University, New Guinea Research Unit (New Guinea Research Bulletin 15).

Jacka, J., 2001. 'Coca-Cola and Kolo: Land, Ancestors and Development.' Anthropology Today 17(4): 3-8.

Lae Archive, 1963/68. 'Forests Upper Watut also Nayti Forest Land.' Lae Archive, Box 263. Lae, Morobe Province, Papua New Guinea.

Lane Poole, C.E., 1935. 'Report on the Forests of the Goldfields of New Guinea: Together with Recommendations Regarding a Forest Policy for the Whole Territory.' Unpublished TS, 1935. NAA, Al 1938/802.

Leach, J., 2001. 'Land, Trees and History: Disputes Involving Boundaries and Identities in the Context of Development.' In L. Kalinoe and J. Leach (eds), Rationales of Ownership: Ethnographic Studies of Transactions and Claims to Ownership in Contemporary Papua New Guinea. New Delhi: UBS Publishers' Distributors and Port Moresby: UPNG Law Faculty Publication Unit.

Li, T.M., 2007. 'Practices of Assemblage and Community Forest Management.' Economy and Society 36(2): 263-93.

Martin, R., 1997. 'Small-Scale Community-Based Forestry: Issues in the Conservation of Papua New Guinea's Biodiversity.' In C. Filer (ed.), The Political Economy of Forest Management in Papua New Guinea. Boroko: The National Research Institute and The International Institute for Environment and Development (NRI Monograph 32).

Mitio, N., 1981. Biangai Marriage and Its Relationship to Kinship and Property: The Case of Werewere Village, Wau District. Port Moresby: University of Papua New Guinea (Honours thesis).

Mitio, N., 1984. Factors Affecting People's Attitudes to Company Exploitation of Their Resources: The Case of Timber. Boroko: Institute of Applied Social and Economic Research (Special Publication 9).

Pacific Islands Monthly, 1939. 'New Guinea's Inland Timbers: Permit for One Firm Only.' Pacific Islands Monthly, 15 March.

Peluso, N., 1992. Rich Forests, Poor People: Resource Control and Resistance in Java. Berkeley: University of California Press. 
Salafsky, N., B. Cordes, M. Leighton, M. Henderson, W. Watt and R. Cherry, 1997/8. 'Chainsaws as a Tool for Conservation? A Comparison of CommunityBased Timber Production Enterprises in Papua New Guinea and Indonesia.' London: Rural Development Forestry Network (Network Paper 22b).

Sekhran, N. and S. Miller (eds), 1995. Papua New Guinea Country Study on Biological Diversity: A Report to the United Nations Environment Programme. Port Moresby: Department of Environment and Conservation, and Africa Centre for Resources and Environment.

Sinclair, J., 1998. Golden Gateway: Lae and the Province of Morobe. Bathurst (Australia): Crawford House Publishing.

Sivaramakrishnan, K., 1995. 'Colonialism and Forestry in India: Imagining the Past in Present Politics.' Comparative Studies in Society and History 37(1): 3-40.

Taylour, H. and I.W. Morley, 1933. 'The Development of Gold Mining in Morobe, New Guinea.' Proceedings of the Australasian Institute of Mining and Metallurgy 89: 1-91.

Waterhouse, M., 2010. Not a Poor Man's Field: The New Guinea Goldfields to 1942 - An Australian Colonial History. Sydney: Halstead Press.

Wau Ecology Institute, n.d., 'Kuper Range Conservation Area and Incentive Promotion Project. Grant Proposal Submitted to the Government of New Zealand.' Unpublished grant application.

West, P., 2006. Conservation Is Our Government Now: The Politics of Ecology in Papua New Guinea. Durham (NC): Duke University Press.

Winkel, G., 2010. 'Foucault in the Forests - A Review of the Use of 'Foucauldian' Concepts in Forest Policy Analysis.' Forest Policy and Economics 16: 81-92.

Wood, M., 2005. 'Charles Lane Poole and Early Forest Surveys of Papua and New Guinea.' Journal of Pacific History 40(3): 289-309. 
This text is taken from Tropical Forests of Oceania: Anthropological Perspectives, edited by Joshua A. Bell, Paige West and Colin Filer, published 2015 by ANU Press, The Australian National University, Canberra, Australia. 